\title{
Numerical modal analysis for vibration-damping properties of ductile cast
}

\author{
Petra Kováčikováa ${ }^{1, *}$, Ján Vavro ${ }^{1}$, Ján Vavro Jr. ${ }^{1}$, Andrej Dubec ${ }^{1}$ \\ ${ }^{1}$ Department of Numerical Methods and Computational Modeling, Faculty of Industrial Technologies, \\ Alexander Dubcek University of Trencin I. Krasku 491/30, 02001 Púchov, Slovak Republic
}

\begin{abstract}
This paper deals with standard test method for the measurement of vibration-damping properties of materials, ductile cast iron - graphitic cast iron with the spherical shape of graphite (ductile cast iron). Investigation is focused on its mechanical properties, chemical composition and microstructure, which are necessary as input parameters for computational modeling and numerical analysis. The vibration or oscillating of experimental samples are closely connected with such parameters as natural shapes (eigenshapes) and natural frequencies (eigenfrequencies). Preparation of a geometric model of a homogeneous beam sample and numerical analysis was performed by finite element method in the ADINA software environment. This paper can be used for further development and growth from the aspect of application of computational tools in the area of damping and eigenfrequency properties for construction materials.
\end{abstract}

Keywords: cast iron, graphite, eigenshapes, eigenfrequencies, ADINA, finite elements methods

\section{Introduction}

Nowadays, increasing demands are being made on machine constructions or parts and equipment in operation. There is the increase of the performance and speed of operating construction and parts during operation, the result of which is formation of undesirable vibrations [1]. This undesirable features and critical machine vibration violation negatively impacts on their life time, reliability, and they may cause a machine damage and accident. Absorption of material vibration can be considered as its diminishing ability. Factors that affect the material damping include viscoelasticity, thermoelasticity, acoustic effects, or magnetism. Other factors include the amount of mechanical stress, load frequency, or temperature. This paper focuses on the sample of cast iron with a globular graphite shape in terms of its microstructure, chemical composition and mechanical properties. Eigenshapes and eigenfrequencies are closely related to the internal damping of the material and therefore the numerical part is focused on the finite element modal analysis [1,2].

\footnotetext{
* Corresponding author: petra.kovacikova@,fpt.tnuni.sk

Reviewers: Vladimír Dekýš, Radim Halama
} 


\section{Material characteristics}

The experimental material was a cast iron with regular grained graphite, the graphite particle size was from 15 to $30 \mu \mathrm{m}$ (Figure 1). From a microstructural point of view, the matrix consists of ferrite and lamellar perlite containing more than $2 \%$. The dispersion of the perlite was from 0.3 to $0.8 \mu \mathrm{m}$ (Figure 2). The microstructure was evaluated according to STN (Slovak Technical Standards) 420461 using the Vega 3 Tescan thermoemission electron microscope.

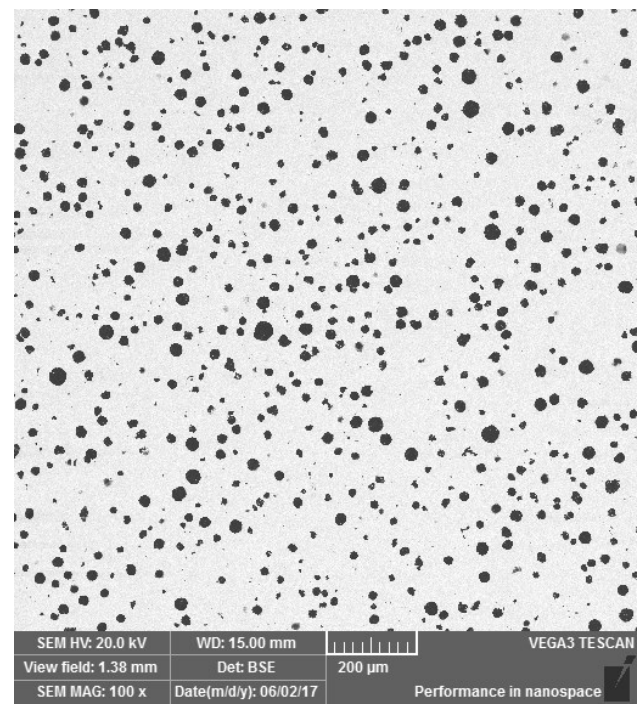

Fig. 1. Regular grained shape of ductile iron graphite

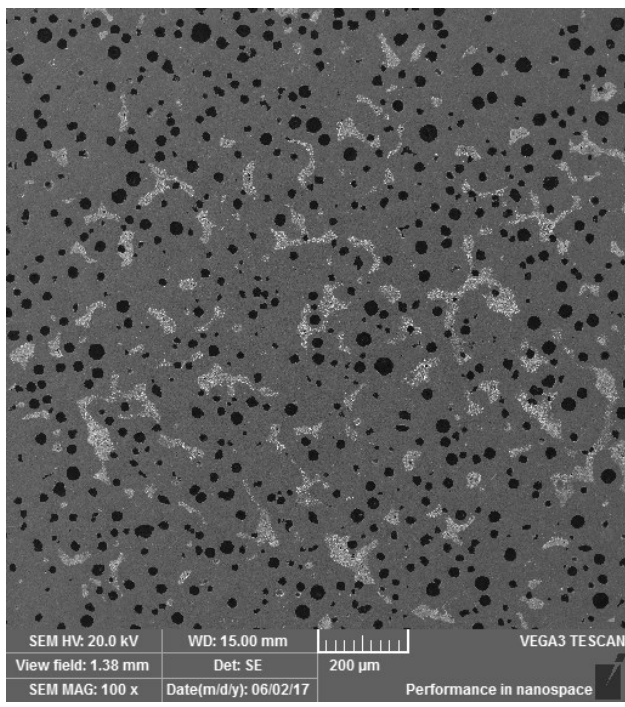

Fig. 2. Ferritic-pearlitic matrix of ductile cast iron

The amount of globular graphite in the structure is referred to nodularity, where this type of graphite can be obtained by modification. The bulb shape of the graphite does not cause a stress concentration in comparison with lamellar type of graphite (Figs 3, 4) [3-5].

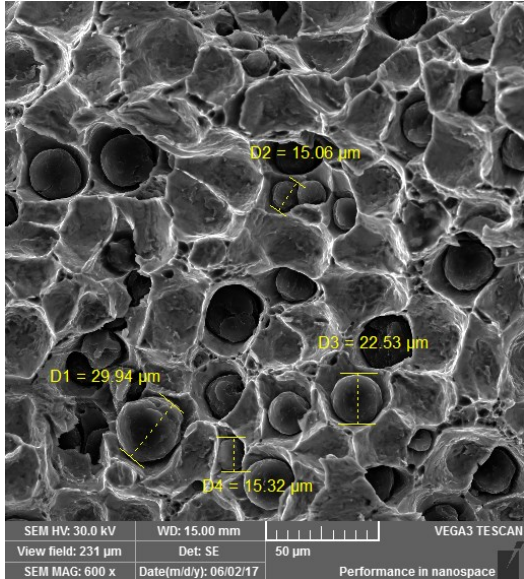

Fig. 3. Cavity micromorphology of the casting surface of ductile cast iron

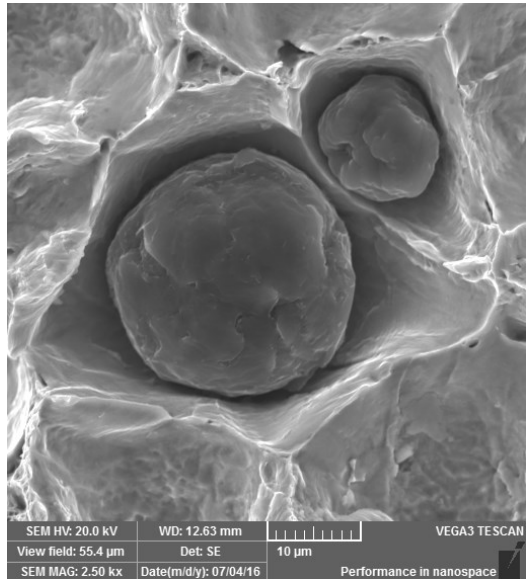

Fig. 4. Detail of globular graphite in the in the fracture area 
The general specification properties for the investigated cast iron of this type can be seen in Table 1. The content of alloying elements of the ductile cast iron was measured from the whole volume of the sample by the EDX-7000 detector (Table 2).

Table 1. Mechanical properties

\begin{tabular}{|c|c|c|c|c|}
\hline $\mathbf{R}_{\mathbf{m}} \mathbf{( M P a )}$ & $\mathbf{R}_{\mathbf{p} 0, \mathbf{2}} \mathbf{( M P a )}$ & $\mathbf{A}(\mathbf{\%})$ & $\mathbf{H B}$ & $\mathbf{E}(\mathbf{G P a})$ \\
\hline $380-900$ & $250-600$ & $2-25$ & $120-350$ & $140-185$ \\
\hline
\end{tabular}

Table 2. Content of alloying elements in wt. \%

\begin{tabular}{|c|c|c|c|c|}
\hline $\mathbf{S i}$ & $\mathbf{C u}$ & $\mathbf{P}$ & $\mathbf{M n}$ & $\mathbf{C a}$ \\
\hline 2.758 & 0.504 & 0.379 & 0.373 & 0.122 \\
\hline
\end{tabular}

\section{Experimental modal analysis}

Experimental modal analysis stands for the process of experimental determination of modal parameters (eigenshapes, eigenfrequencies) of linear systems. The way and the method of experimental measurement are standardised. The damping properties of the material can be used with mathematical models to design damping systems and they can be also applied for prediction of their performance. A comparison of damping capabilities is in the Figure 5.

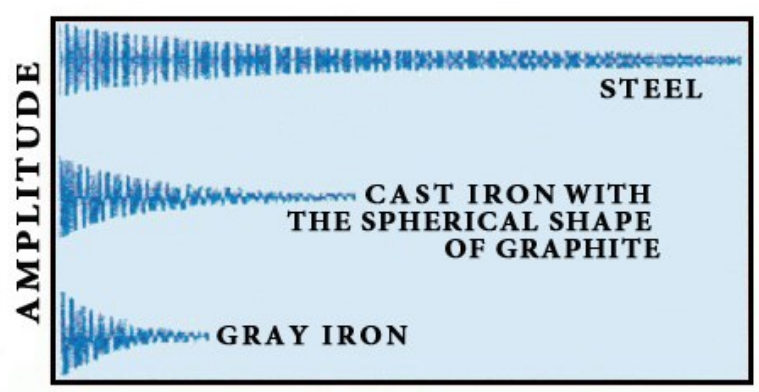

T I ME

Fig. 5. Comparison of steel and cast iron damping capabilities

The damping structure based on homogeneous layer representing the tested beam sample has good results, but in some applications the damping structure may consist of two or more layers with significantly different properties. The simplest frequency transmission requires the use of a two-channel frequency analyzer with a single channel for input or excitation measurement and a second channel for output or response measurement. The schematic image of the device for measuring of the damping properties is shown in Figure 6. As a part of the measuring device, the multi-analyzer PULSE 12 software system for vibro-acoustic measurements is used for evaluation of measurement results. When examining the dynamic effects of an excitation system, it is necessary to take into accout the linearity of the system and this fact means that the response of the system is directly proportional to the corresponding excitement $[1,2,6,7,8]$. 


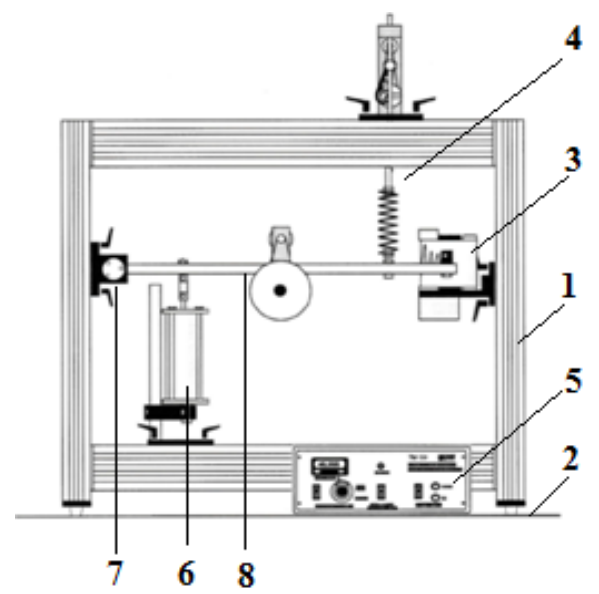

Fig. 6. Detailed description of the measuring device: 1-frame, 2- base board, 3-mechanical drum recorder, 4-suspension of free end from a helical spring, 5- control unit for excitation frequency, 6regulation unit (attachment of springs, exciter and damper), 7- fixed mount, 8- tested beam sample

\section{Results and discussions of numerical analysis}

The eigenshapes (natural shapes) and eigenfrequencies (natural frequencies) represent an important factor in oscillation of structural materials. The model of sample had precisely defined dimensions and it was according to ASTM E756. Measurement of the homogeneous beam sample (Figure 7) was performed from the aspect of the strength and damping properties of the materials, while the input parameters of the investigated ductile cast iron were predefined and modal analysis (Figure 8) was performed using the finite element method in the ADINA software environment [1].

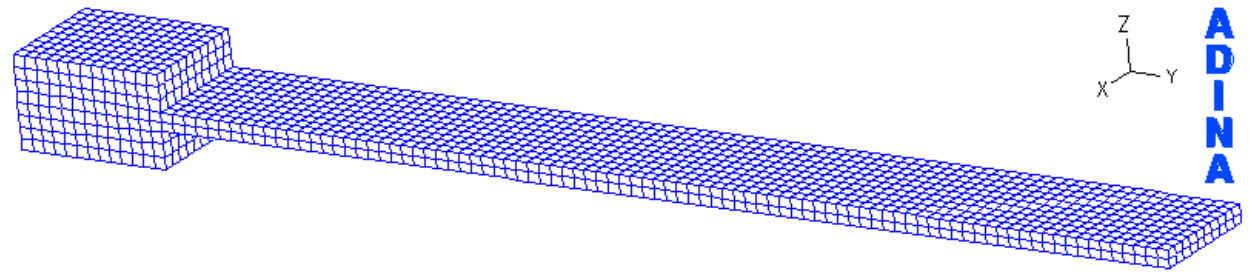

Fig. 7. Sample Model based on Finite Element Method

Table 3. Obtained frequencies for individual eigenshapes

\begin{tabular}{|c|c|}
\hline Eigenshapes & Frequency $(\mathbf{H z})$ \\
\hline 1 & $7.76591 \mathrm{E}+01$ \\
\hline 2 & $4.86928 \mathrm{E}+02$ \\
\hline 3 & $5.11581 \mathrm{E}+02$ \\
\hline 4 & $1.30376 \mathrm{E}+03$ \\
\hline 5 & $1.36697 \mathrm{E}+03$ \\
\hline 6 & $2.69083 \mathrm{E}+03$ \\
\hline 7 & $3.04368 \mathrm{E}+03$ \\
\hline
\end{tabular}




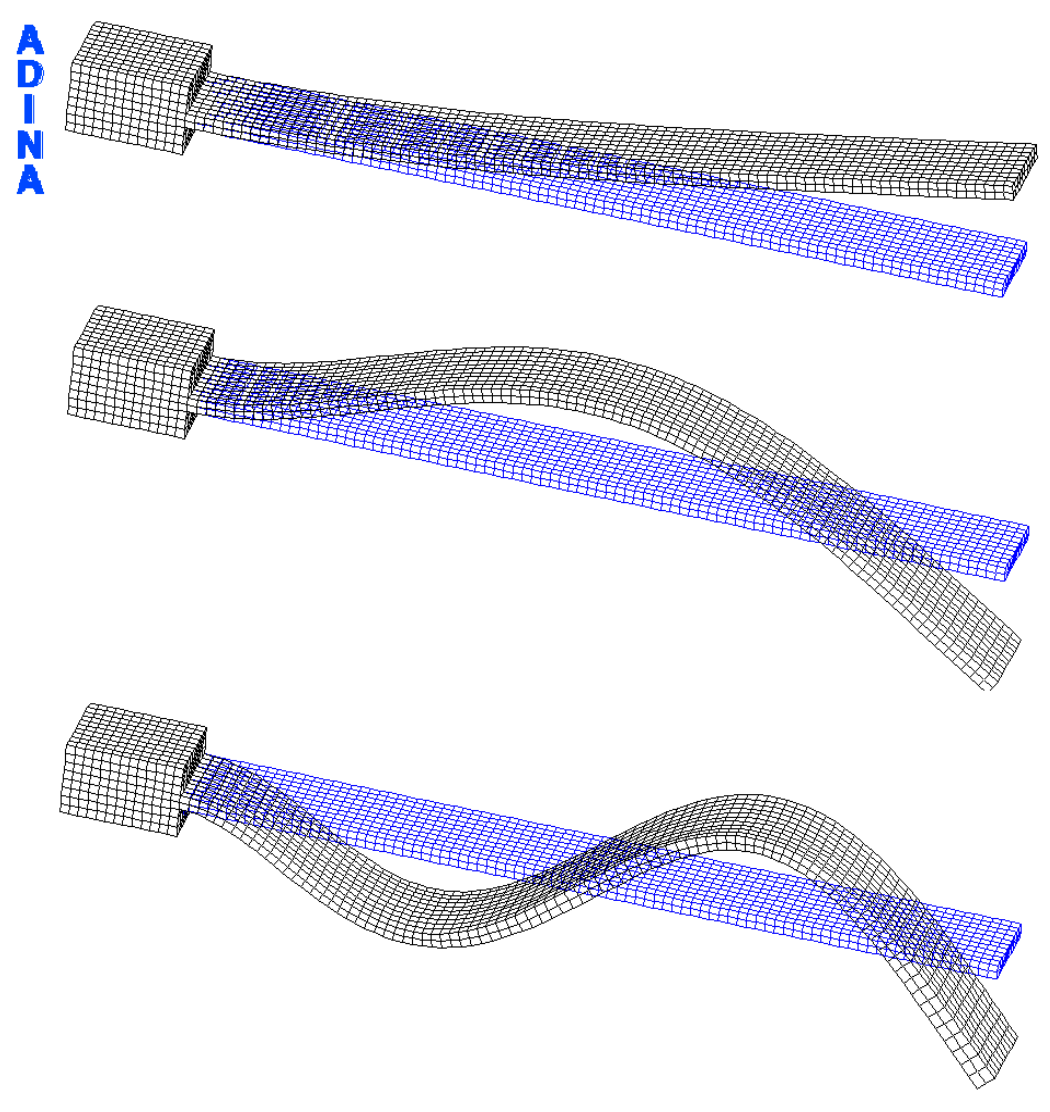

Fig. 8. Selected first eigenshapes of the homogeneous beam

\section{Conclusion}

In production of heavy duty machines and devices, which have to operate under the continuous cyclic loading, the dumping properties (including acoustics - noise and vibrations) have to be taken into account, because the increased vibrations have a negative effect on functionality of operating machines, which can be totally damaged or they can even cause any accident. Based on the verification of the results from numerical analysis and specified experimental measurement, it would be possible to determine the most suitable material to be used for high stressed parts, with are going to be made of the ductile cast iron. The mentioned facts make us look for ways to improve of limiting technical parameters and operating efficiency by selection of the right material. Modal analysis is a field of study that combines signal processing and computational interaction, mechanics theory, oscillation, acoustics, applied mathematics, and engineering prediction. Internal damping occurs in the structure of the material and can be caused by imperfection of this material. It is therefore necessary to have all important knowledge about the specific material before its usage in the operation. 
This paper deal was supported by the Slovak Grant Agency KEGA 007TnUAD-4/2017, VEGA grant No. 1/0649/17, VEGA grant No. 1/0589/17 and resulted from the project "Centre for quality testing and diagnostics of materials", ITMS code 26210120046 relating to the Operational Program Research and Development funded from European Fund of Regional Development.

\section{References}

1. J. Vavro, Numerická analýza napätových stavov štruktúr grafitických liatin. (Žilina, 76 p., 2013) ISBN 978-80-8075-614-7

2. A. Puškár, Vnútorné tlmenie materiálov. (Žilina, EDIS, 382 p., 1995) ISBN 80-7100260-7

3. M. Handrik, L. Jakubovičová, P. Kopas, M. Sága, Analysis of microplastic areas near graphite particles of nodular cast iron loading bellow yield stress. Metalurgija (Metalurgy) 49 (2), 263-267, ISSN0543-5846 (2010)

4. STN 42 0461, Hodnoceni metalografické struktury litin. (Praha, ÚNM, 16 p., 1977)

5. P. Skočovský, T. Podrábský, Grafitické liatiny. (Žilina, EDIS, 168 p., 2005) ISBN 808070-390-6

6. Standart test method for measuring vibration-damping properties of materials. (Code ASTM E 756-04, ASTM International, 2004)

7. D. J. Ewins, Modal testing: Theory and Practice. (Gilliard, Great Yarmouth, 269 p., 1988) ISBN 0-86380-017-3

8. A. Bilošová, Experimentální modálni analýza. (VŠB - Technická univerzita Ostrava, Ostrava, 104 p., 2006) 